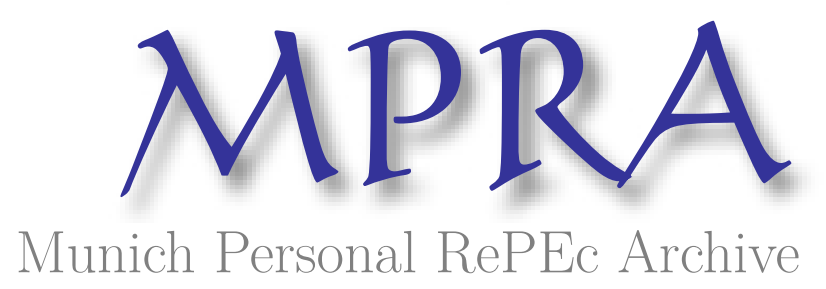

\title{
The Patterns of cross-border portfolio investments in the GCC Region: do institutional quality and the number of expatriates play a role?
}

Balli, Faruk and Louis, Rosmy J. and Osman, Muhammed

Massey University, Vancover Island University, University of Dubai

1 January 2009

Online at https://mpra.ub.uni-muenchen.de/19966/

MPRA Paper No. 19966, posted 14 Mar 2011 21:14 UTC 


\title{
The patterns of cross-Border portfolio investments in the GCC region: do institutional quality and the number of expatriates play a role?
}

\author{
Faruk Balli \\ Massey University
}

\author{
Rosmy J. Louis \\ Vancouver Island University
}

Mohammad Osman

University of Dubai

March 9, 2010

\begin{abstract}
In this paper, we document the determinants of portfolio investments to Gulf Cooperation Council (GCC) economies by bringing up the role played by market forces, cultural affinities, and institutional quality. We classify the GCC economies as host to 35 countries as per the Coordinated Portfolio Investment Surveys (CPIS) of the IMF for the period 20012006. Using the CPIS data and data from various other reliable sources and appropriate panel data analysis techniques, we find a number of interesting results: 1) the relatively higher quality of institutional set up in GCC in comparison to other countries; 2) the relative volume of expatriates across source countries in GCC soil; and 3) bilateral factors such as trade linkages between GCC and source countries, all statistically and significantly explain portfolio investments to the GCC region. Additionally, we uncover the existence of a portfolio "GCC bias". That is, GCC investors exhibit a strong preference towards their own markets when allocating their cross border financial asset holdings.
\end{abstract}

JEL classification: E44, F15, F36, F41

Keywords: International Portfolio Allocation, GCC, Bilateral Linkage, Institutional Quality, Expatriates. 


\section{Introduction}

The objective of this paper is to shed lights on the determinants of portfolio investments to Gulf Cooperation Council(hereafter GCC) countries by investigating the role played by market forces, labor in-migration, cultural affinities, and institutional quality. The GCC is an interesting case begging for in-depth understanding of capital inflows for many reasons. Following the oil crisis of the 1970s and early 1980s, the GCC had seen the largest increase in oil and gas export revenues. Although part of this money was invested at home to build infrastructure and develop the agricultural sector, a large portion was also allocated to finance investment in the United States and Europe and heavy weaponry. These investments took place to respond to two urgencies at the time: the need for protection against political instability and conflicts in the region and

the need to reduce reliance on oil revenues. During the 1970s and the 1980s when war was raging in the Middle-East, it was inconceivable for the rather risk-averse investors to allocate their portfolio in the region since the people who live there and the governments themselves were expatriating capital in the hope of not losing it all at once in a conflict. Moreover, in most of these countries, the law did not permit foreigners to own properties and have their own businesses without a local sponsor.

Although massive investments of GCC oil revenues in US and European markets have solidified political relationships with the West and have provided the much needed protection to keep the political landscape intact, domestic macroeconomic structural reforms did not deliver the good as anticipated. It did not take long for these countries(mostly Saudi Arabia) to realize that supports to the agricultural sector for example out of oil revenues were not the best usage of financial resources when oil prices tumbled in 1983 and thereafter(Hourani 2004). However, a series of unfortunate events that took place in the 1990s and 2000s has brought to the GCC the opportunity to correct the mistakes of the past as oil and gas prices were climbing again to reach record levels in 2000 and thereafter. Also, these events have changed the patterns of portfolio investments to GCC countries. With the September-11 attack on US soil, many individuals of Arab descent who had investments in the US and other western countries were looking for a safe haven as fear was mounting that these countries might freeze their capital alleging that they have ties to terrorist organizations. No other countries in the Middle-East and Africa represented a better alternative than the GCC region. The invasion of Iraq in 2003 and the rise of extremism giving rise to a halt in the production of oil in Iraq and a reduction in the world supply of crude oil and natural gas have also benefited the GCC as the price of oil had reached levels never seen before.

With the new windfall of oil and gas revenues, the GCC has this time adopted a different 
strategy by investing in industries in which they can build a competitive advantage. These include petrochemical, banking and financial services, airline, tourism, real estate, telecommunications, steel, and transportation, to cite just a few (Fasano and Iqbal 2003). In terms of portfolio investment allocation, a wider range of countries in the Middle-East, North Africa, and Asia have received their fair share while the US and Europe continue, due to political reasons, to receive the largest portion(Molavi 2007 and World Bank 2005). What this new strategy seems to have created is a reciprocal and trustworthy partnership that also attracts capital from investors of these regions and the rest of the world to the GCC. Since governments are majority shareholders and exercise control in most of the major companies, the overly riskaverse investors are reassured that their investments are in good hands since governments are less likely to go bankrupt. As a result, initial public offerings (IPOs) by companies are often oversubscribed, reflecting investors' drives for a share of previously wholly-owned companies by nationals and newly-formed corporations. Since the GCC stock markets are fairly new, share prices are initially offered at a bargain and returns are fairly substantial. Bley and Chen (2006) report that, in 2004 alone, foreign portfolio holders collected between 150 and 170 billion US dollars in profits from the GCC countries.

Along with the massive investment brought about by rising oil revenues, fiscal disciplines coupled with low interest rates (on average between 3 and 4 percent in some cases) have also helped the GCC in creating macroeconomic conditions amenable to an orderly dynamic business environment. Translation costs and uncertainty about capital repatriation are minimal due to these countries' long ties with the US dollar as their anchor currency. Reforms to further enhance benefits from technology transfer and massive capital inflows have been initiated in terms of new laws to protect property rights, combat corruption, and to ease ownership restrictions and immigration. These measures contrast squarely with the external environment in the Middle-East, Asia, and Africa where corruption, political upheaval, and poverty hinder economic development. The misfortune of the region has offered to the GCC a pool of cheap labor to capitalize on as they expand ambitious projects of infrastructure. The GCC's commitment to foster both vertical and horizontal capital inflows as an important engine of their economies can be seen as a smart move as they are moving away from oil dependency to create industry and service-based economies capable of rivaling other economies in the international markets. The combined outcomes of this overall dynamic are that the GCC markets have become more and more important over the years for investors seeking higher returns and workers seeking better opportunities and for countries seeking investment projects. ${ }^{1}$

\footnotetext{
${ }^{1}$ It is expected that by 2020 , GCC countries could rival rising economies such as Brazil, China, and India if
} 
There have been some previous attempts at documenting the determinants of capital inflows to the Middle-East and North Africa. For example, in their study of international portfolio allocation, Lagoarde-Segot and Lucey (2007) find that risk diversification and the drive for higher profits explain investors' inclination for the region. Sadik and Bolbol (2001) provide evidence of linkages between capital flows/foreign direct investment (FDI) and technology spillovers. They have shown that contributions to technology and productivity can emanate from FDI as well as other forms of capital formation. Mina's (2007) examination of the location determinants of FDI inflows to the GCC could not find that FDI is stimulated by the production, prices, and proven reserves of oil. He instead found that relative oil utilization encourages FDI. These contributions without a doubt have deepened our understanding of portfolio inflows to the region in general and to the GCC in particular. However, the picture is still incomplete when a number of important factors such as investors' preferences, regional and home biasness, labor in-migration, and relative institutional quality are being overlooked or not being compared to other successful regional blocs. In these respects, the present paper complements the existing literature in several aspects. It is to our knowledge, a primer for the GCC if not the whole Middle-East and North-Africa regions. We therefore argue that external environment, economic fundamentals, countries' specific characteristics, economic ties between source and host countries, institutional quality of the host country relative to other potential host countries, the level of real income of source countries and the financial openness of the host country all can potentially explain international portfolio inflows to GCC countries. Most importantly, it is well known that factors such as distance, financial innovations, capital mobility, and the number of nationals from the source countries residing or working in the host country tend to strengthen economic ties amongst nations. For example, an Indian investor would find it easier to invest in, export and/or import to the GCC where Indians constitute the majority of the population of workers in comparison to other non-GCC countries. Therefore, the interesting question that we raise comes quite naturally: Can institutional quality, the number of expatriates, economic linkages between hosts and source countries and/or socio-cultural affinities explain the patterns of cross-border portfolio investments in the GCC region?

We investigate the patterns of portfolio allocation to GCC financial markets using panel data analysis and compare the findings with those obtained for the OECD countries. Our results show that, in line with earlier contributions to the literature, bilateral factors such as trade volumes and the source country's share of world market capitalization play a significant

their plan to enter a monetary union by 2010 and issue a common currency goes smoothly. Bley and Chen (2006), Guetat and Serranito (2007), and Alkulaib et al. (2008) have already associated the strong economic growth of the GCC countries to the ongoing economic and financial integration of the region with the rest of the world. 
role in portfolio allocation to the GCC region. There is also a strong portfolio "GCC bias". That is, a large share of the GCC investment comes from GCC members themselves. This bias is similar in nature to the portfolio Euro bias also observed. ${ }^{2}$ It is the notable consequence of not only the high level of financial and economic integration that characterizes the GCC countries but also a reflection the ripple effect of post-September-11 reactions. We find that institutional quality is statistically significant in all estimated models indicating that investors' perception about the quality of institutions is an important factor in portfolio allocation. The GCC receives a larger chunk of foreign portfolio investment because it has higher institutional quality relative to other competing countries in the region. Additionally, we explore the effect of labor in-migration to the GCC on capital inflows. We find that the greater the number of expatriates originated from a given source country living in the GCC the higher the volume of portfolio inflows from that country to the GCC. This can be explained by the unique structure of the GCC members where more than $80 \%$ of their population are non-resident aliens. The resulting effects are higher volume of goods and services traded (frequent trips back home), higher volume of remittances transferred and lower transaction costs.

The remainder of the paper is organized as follows. Section 2 presents a multi-market portfolio model relating international portfolio allocations with bilateral linkages. Section 3 describes the data set and the construction of some of the key variables of interest. Section 4 presents the empirical findings and analyzes the determinants of cross border asset holdings. Section 5 presents the robustness check and Section 6 concludes the paper.

\section{Model}

\subsection{Bilateral Linkage Model}

The underlying framework of this paper is the original Obstfeld and Rogoff (2001) model where trading costs play a crucial role in explaining empirical macroeconomic puzzles. This framework has proven to be useful in addressing home bias puzzles in French and Poterba (1991). Lane and Milesi-Ferretti (2008) have extended the Obstfeld and Rogoff's model to N countries in order to show that existing trading costs in the goods market and individual preferences affect bilateral equity positions in both industrial and developing nations. The N-country model of Lane and Milesi-Ferreti (2008) postulates that the home country's share of equity that is held by the foreign country is a decreasing function of the trading costs between the home and the

\footnotetext{
${ }^{2}$ See Baele et al. (2003), Lane and Milesi- Ferretti (2005). Also Balli et al. (2009) implemented similar work for GCC region with a shorter period of time.
} 
foreign country and an increasing function of the real time importance of the good that is being traded. We use the same framework to shed lights on the international portfolio inflows to GCC countries.

Theoretically, there are $\mathrm{N}$ countries in the world and each country is endowed with a stock of perishable goods that is random. Output is unevenly produced across countries and there is a complete set of Arrow-Debreu (AD) securities in the capital markets. The model assumes that individuals hold cross-border portfolio in only one period as they attempt to maximize their expected utilities. We partition the $\mathrm{N}$ countries into two: $h$ home country and $j$ foreign countries. The expected utility of the representative consumer in the home country is given by:

$$
E U_{h}=E\left\{\frac{1}{1-\rho}\left(\left[\sum_{j=1}^{j=N} \varpi_{i j} C_{i j}^{\frac{\alpha-1}{\alpha}}\right]^{\frac{\alpha}{\alpha-1}}\right)^{1-\rho}=E \frac{C_{h}^{1-\rho}}{1-\rho},\right.
$$

where $\varpi_{i j}$ is the relative preference by consumers in country $j$ for good $i, C_{h}$ is the index of total real consumption, $\alpha$ is the elasticity of substitution between any two goods and $\rho$ is the coefficient of relative risk aversion.

There are iceberg shipping costs $\eta$ only a fraction of a unit of a good shipped from country $h$ to country $j$ reaches to the destination. Accordingly, $\eta_{h j}$ is greater than zerowhile assuming there are no shipping costs for good $i$ within the foreign country $\eta_{j j}=0$, or within home country, $\eta_{h h}=0$. In addition, we normalize $\varpi_{j j}=1$.

Perfect competition in product markets requires that

$$
P_{i h}=\left(1-\eta_{h j}\right) P_{i j},
$$

where $P_{i h}$ and $P_{i j}$ denotes the price of good i in countries $h$ and $j$ respectively. In the model, we have free traded Arrow-Debreu securities where the marginal utility per dollar for good $i$ across countries must be the same for the last units consumed. Put differently, the ratio of marginal utility derived from the consumption of good $i$ must be equal to the relative price of good $i$ across the two countries.

In other words,

$$
\begin{gathered}
\frac{1}{P_{i h}} \frac{\partial U}{\partial C_{i h}}=\frac{1}{P_{i j}} \frac{\partial U}{\partial C_{i j}} \\
C_{i h}^{-1 / \alpha} C_{h}^{1 / \alpha-\rho}=\left(1-\eta_{h j}\right) \varpi_{h j} C_{h j}^{-1 / \alpha} C_{j}^{1 / \alpha-\rho}
\end{gathered}
$$


under the simplifying assumption where $1 / \alpha=\rho$

$$
C_{i j}=\left(1-\eta_{h j}\right)^{\alpha} \varpi_{i j}^{\alpha} C_{i h}
$$

The goods market equilibrium is

$$
Y_{i}=C_{i h}+\frac{P_{i j}}{P_{i h}} * C_{i j}
$$

If we generalize the output clearing condition to $\mathrm{N}$ markets,

$$
Y_{i}=\sum_{j=1}^{j=N} \frac{C_{i j}}{\left(1-\eta_{i j}\right)}
$$

In line with $\mathrm{AD}$ securities, the ratio of home to foreign consumption of goods must be equal to net asset inflows to the home country from the foreign country.

$$
\theta_{h j}=\frac{P_{h j} * C_{h j}}{\sum_{j=1}^{N} P_{h j} * C_{h j}}
$$

After appropriate substitution of equations 5 and 7 into equation 8 , we get;

$$
\theta_{h j}=\frac{\left(1-\eta_{h j}\right)^{\alpha-1} \varpi_{i j}^{\alpha}}{\sum_{j=1}^{j=N}\left[\left(1-\eta_{h j}\right)^{\alpha-1} \varpi_{i j}^{\alpha}\right]} Y_{h}
$$

Under the simplifying assumption that $1 / \alpha=\rho$, this allocation can be achieved by foreign asset trading. The allocation means that country $j$ holds a larger share in country $h$ 's equity, the lower is the transportation cost between countries $h$ and $j$ relative to the average transport cost between country $h$ and all other countries; and the greater is the relevant importance attached to good $i$ in country $j$ 's consumption preferences.

By taking the logarithm of Equation (9), we obtain

$$
\log \left(\theta_{h j}\right)=(\alpha-1) \log \left(1-\eta_{h j}\right)+\alpha \log \left(\varpi_{h j}\right)-\log \left(\sum_{j=1}^{j=N}\left[\left(1-\eta_{h j}\right)^{\alpha-1} \varpi_{h j}^{\alpha}\right]+\log Y_{h}\right.
$$

The very last two terms are fixed terms for both home and foreign country. Therefore we can 
represent those terms as constant terms. This allows us to further simplify the expression to ${ }^{3}$

$$
\log \left(\theta_{h j}\right)=A_{h}+(\alpha-1)^{*} \log \left(1-\eta_{h j}\right)+\alpha^{*} \log \left(\varpi_{h j}\right)
$$

This reduced form will help us to test the model empirically. In the reduced form, directly, transportation costs and consumer preferences are not observable, but may be captured by a host of proxy variables. The linear model can be set up as follows;

$$
\log \left(1-\eta_{h j}\right)=\lambda \chi_{h j}^{\tau}+v_{h j}^{\tau}
$$

and

$$
\log \left(\varpi_{h j}\right)=\lambda \chi_{h j}^{\varpi}+v_{h j}^{\varpi}
$$

Obviously, the vectors could be overlapping sets in that the parameters may not be individually identifiable. In the end, we obtain a reduced form equation or model, with the vectors $\chi_{h j}$ embedding the proxy estimates for bilateral factors, such as distance between the source and host country, trade competition in third markets, cultural linkages, lending from foreign to home country and bilateral trade volumes between home and foreign country. ${ }^{4}$

\section{Data}

We use a broad sample of countries to capture the patterns of international portfolio inflows to GCC markets. We classify GCC as host countries to 35 countries, which are listed in the Table 1, as source countries. The data set for this paper originates from various sources as detailed in Table 2. We obtain a pair-wise volume of cross border portfolio holdings in US dollars from the International Monetary Fund's Coordinated Portfolio Investment Surveys (CPIS) for the period 2001 to 2006. These are reliable surveys that use consistent guidelines in measuring holdings of equity and bonds across countries. We could not use the survey data collected for the years 1994 and 1997 due to the unavailability of data for the GCC countries, which by and large have fairly new financial markets and have recently opened the non-oil sector of their economies to the rest of the world.

${ }^{3}$ When we changed the order of the countries, the equation will be as follows;

$$
\log \left(\theta_{j^{*} h}\right)=(\alpha-1) \log \left(1-\eta_{j^{*} h}\right)+\alpha \log \left(\varpi_{j^{*} h}\right)-\log \left(\sum_{j=1}^{j^{*}=N, j \neq j^{*}}\left[\left(1-\eta_{j h}\right)^{\alpha-1} \varpi_{j^{*} i}^{\alpha}\right]\right)+\log Y_{j^{*}}
$$

the very last two terms will be the fixed effect of the foreign country pair. In the empirical model, the constant effects for both host(home) and source(foreign) country have been used accordingly.

${ }^{4}$ We use bilateral factors which are available for the GCC markets. 
We construct two variants of portfolio holdings from the data set by looking at portfolio flows from source to host country. The first variable is the total foreign portfolio, which is the sum of debt and equity securities while the second one is just composed of pure debt securities. We discarded a third variable that could have purely embraced financial assets originating from equity securities transactions because the volume as well as the allocations of equities to GCC markets are very limited and most of the times biased towards certain markets. The CPIS dataset also reveals that the majority of foreign portfolio holdings from the GCC markets are debt securities. This perceptible feature of the data supports our approach in focusing on both total portfolio inflows and total debt securities, not on equities alone as a dependent variable.

Following Sørensen et al. (2007), we construct a variable on total market capitalization by taking the weighted average of bond and equity markets capitalization for each country. We measure the size of a country's total bond market capitalization as outstanding domestic debt securities minus outstanding short term domestic securities plus outstanding international bonds and notes. ${ }^{5}$ We create the variable on total market capitalization of equity markets by taking the weighted average of the bond market and the equity market capitalization of each country. Intuitively, we expect that the higher market capitalization of source country, higher portfolio holdings from GCC region is expected.

Measuring capital control has always been a dilemma for researchers since it is difficult to distinguish between pure capital inflows and capital inflows that originate from the relaxation of rules and policies. We follow Chinn and Hiro (2007) in constructing a variable that measures the level of financial openness of GCC markets. Chinn and Hiro (2007) broadly define capital openness, as a set of dummy variables while taking into consideration the set of restrictions on cross border financial transactions reported in the IMF's Annual Report on Exchange Arrangements and Exchange Restrictions (AREAER). These include variables indicating:

- the presence of multiple exchange rates $(\mathrm{k} 1)$

- restrictions on current account transactions $(\mathrm{k} 2)$

- restrictions on capital account transactions (k3);

- the requirement of the surrender of export proceeds $(\mathrm{k} 4)$.

Among the binary variables on capital openness, the one related to restrictions on capital account transactions is key in the determination of international portfolio allocation. Accordingly, we trace this variable, $(\mathrm{k} 3)$, over time and take its average over a five-year period to build our

\footnotetext{
${ }^{5}$ Short-term securities are defined as securities with maturity of less than a year.
} 
own dummy variable. Our objective is to be able to observe the effects of the changes in capital restrictions in a broader scope. Analogous to Mody and Murshid (2005) and Chinn and Hiro (2007), we create the binary variable on capital restriction by considering financial openness rather than the existence of capital restrictions or not. Our dummy variable takes the value of 1 when the country does not have capital control restrictions and 0 otherwise.

The capital control variable is constructed as follows:

$$
\text { CAPITALCONTROL }=\frac{k_{3, t}+k_{3, t-1}+k_{3, t-2}+k_{3, t-3}+k_{3, t-4}}{5},
$$

where $k_{3, t-n}$ is the dummy variable for the capital restriction decision by IMF's Annual Report on Exchange Arrangements and Exchange Restrictions (AREAER) $n$ years ago.In the empirical analysis, we expect that countries having less capital restrictions will be exposed higher foreign liabilities.

\subsection{Institutional Quality and Freedom Indices}

Institutional quality is measured using the corruption perception index of Transparency International. This index has been used in a number of previous studies, and a review of both the index. ${ }^{6}$ The index measures institutional quality in five major areas: (1) size of government, (2) legal structure and security of property rights, (3) access to sound money, (4) exchange with foreigners, and (5) regulation of capital, labor, and businesses. Alternatively, collected since the 1970s by the Freedom House, the Freedom House index measure of political rights and civil liberties is a group of indices that assess countries on the basis of a wide range of criteria including political rights, civil rights, freedom of expression of beliefs, rule of law, and functioning of government. We use two of such indices: the functioning of government and the civil rights to gauge the quality of institutions of the source country relative to the host country when allocating their portfolio. Portfolio holders are able to use the institutional quality as a proxy for the default risk measurement of both source and host country. Therefore, relatively lower institutional quality in the source country compared to the host country, higher portfolio allocation in host country is expected.

Other variables used in the panel estimation include: total debt to GDP ratio, bilateral linkage variables (distance, trade volume between hosts and source countries, and the number of expatriates originated from source country to host country, binary variables like having common language and common colonial past, and having same). ${ }^{7}$ Debt to GDP ratio, just

\footnotetext{
${ }^{6}$ To cite just a few; Husted (1999) Habib and Zurawicki (2002) Svensson(2005), Seligson (2007).

${ }^{7}$ The sources and explanations about these variables are incorporated in Table 1.
} 
like institutional quality, is used to be a proxy for the measurement of default risk. We used debt to GDP ratio to account for the importance of solvency in capital markets. Relatively higher debt to GDP ratio does the source country have, portfolio investors of that country seek for other markets to decrease the default risk. Therefore we expect to have higher portfolio holdings when the relative debt to GDP ratio increases. PPP adjusted GDP is used to proxy the wealth and income level of the source country. Naturally, as the income level of the source country increases, the residents want to allocate the extra wealth to different markets and there will be more portfolio investments to the host countries. The bilateral linkage variables indicate the stronger linkages between the source and host country. Having stronger linkages help to create comparative advantage in transferring financial securities(lower transaction costs, faster transfer, etc), therefore we expect positive effect (except distance) in the empirical analysis. Last, religion dummy will be a proxy to measure the cultural similarities, in particular for those muslim investors seek for the markets that will have non-interest bearing assets, we expect to have higher portfolio holdings when the source country's population is dominated by muslim residents.

\section{Empirical Model}

In this section, we estimate the reduced form equation of Lane and Milesi-Feretti's (2008) Ncountry portfolio model to uncover the main determinants of international financial asset inflows to the GCC markets. The regression equation is given by;

$$
\theta_{t}^{h j}=\alpha_{t}^{h}+\alpha_{t}^{j}+\beta_{0, t}^{*} \mathrm{DEBT}_{t}^{j-h}+\beta_{1, t}^{*} \mathrm{GCC}_{t}+\beta_{2, t}^{*} Z_{t}+\beta_{3, t}^{*} X_{t}+\epsilon_{t}
$$

where the dependent variable, $\theta^{h j}$, is the log volume of source country $(j)$ 's foreign portfolio allocated in host country $(h) ; \alpha^{h}$ and $\alpha^{j}$ are the corresponding fixed effect variables of host and source country respectively(double fixed effects). ${ }^{8}$ Market capitalization rate and Purchasing Power Parity (PPP) adjusted real GDP per capita are used to gauge the source country fixed effect, financial openness is employed for the host country fixed effect. DEBT ${ }^{j-h}$ is the debt to GDP ratio differential between source and host country. To account for the importance of solvency in capital markets, we consider the effect of fiscal indebtedness of debtor countries on the bonds market. We use the external debt differentials in a way that enables us to test the significance of both fixed effects. Furthermore, we create a number of variables, namely, GCC

\footnotetext{
${ }^{8}$ We included the fixed effects in accordance with the Hausman test. It is a test of testing if the random effects are consistent and efficient. ( $H_{0}$ : that random effects is consistent and efficient, versus $H_{1}$ : that random effects would be inconsistent.) We found that Chi-square value is large enough to(55.13) to reject the null hypothesis.
} 
and $Z_{t}$ to test for bilateral linkages between source and host countries. GCC is a dummy variable that takes the value of 1 if the source country is a member of the GCC block and 0 otherwise. $Z_{t}$ is a set of cultural, demographic, and institutional variables that regroup institutional quality, expatriates, and religion. Religion takes the value of 1 if the dominant religion in the source country is Islam and 0 otherwise whereas institutional quality is an index whose scale varies from 0 to 10 , with 10 being the highest quality. Since this variable is in relative terms, we therefore anticipate an inverse relationship between source countries' institutional quality relative to the GCC and capital inflows to the GCC. Put differently, the lower the quality of institutions in a source country relative to the GCC, the higher the capital inflows to the GCC. Similar reasoning applies to the Freedom variable, which is an index that varies from 1 to 7 , with 1 representing complete freedom and 7 the absence of the same. We employed the freedom index as a robustness check variable to check if our model has been affected from different institutional quality measures. Expatriate is a variable that captures number of citizens from the source countries earning a living in the GCC. Lastly, $X_{t}$ contains bilateral factors such as export volume from source country to host countries in U.S Dollars, distance in kilometers between the capital city of the source country and the host country, and binary variables including; having common language and common colonial past. All but the discrete and index variables are in logarithmic forms.

\section{Empirical Results}

In the empirical analysis, we employ multivariate panel data regression techniques to uncover the determinants of portfolio inflows to GCC and also compare our findings with the OECD countries for the period 2001-2006. ${ }^{9}$ Panel and instrumental variable (IV) estimators are used to arrive at the coefficient estimates and the main results are presented in Tables 3 to 5 . We test the robustness of our findings with regard to the choice of estimators and run a separate set of regression using Censored Normal Tobit. The results are inserted in Table 6. Unless otherwise specified, our analysis is based on a significance level of $5 \%$. Nonetheless, we indicate all the significance levels on the Tables. Only the explanatory variables for which there are variations over the sample are incorporated in the regressions. Tables 3 to 5 contain each three columns of estimates of the reduced form model of Equation 16. Column 1 showcases the results related to variables commonly used in the literature to gauge the determinants of capital inflows. Column 2 presents, in addition to the usual variables, coefficient estimates of the cultural, demographic,

\footnotetext{
${ }^{9}$ The volume of foreign asset inflows as well as the number of investors with stakes in GCC markets are quite limited in 2001, however, both the number and the volume have increased gradually in the years after.
} 
and institutional variables that we conjecture explain the volume of foreign assets holdings in the GCC. A comparison of these first two columns clearly delineates our contribution to the existing literature. Additionally, considering the dependency of the level of imports of the host country from the source country, we used the instrumental variables to solve the endogeneity problem Column 3 repeats the same exercise using the Instrument variable(IV) estimator. We treat as potentially endogenous variables for the level of imports. Our instrument list consists of; distance, a contiguous dummy, the lagged the level of imports, common language dummy, similar country dummy. ${ }^{10}$

The first column in Table 3 shows that coefficient estimates for variables such as the import volume, foreign market capitalization, capital control, and GCC are positive and statistically significant in explaining the volume of portfolio inflows to GCC markets. These findings confirm that goods and services and capital markets integration are important in attracting investments across countries. Lane and Milesi-Ferretti (2008) have reported a similarly strong positive relationship between the bilateral trade volume and portfolio inflows using the 2001 survey data of the CPIS. We also find the differential of debt to GDP ratio is significant at the 10 percent level whereas distance between source and host country, and cultural affinities represented by common language and colonial past are statistically insignificant, though they have the correct signs. Two surprising results, however, have emerged: the PPP-adjusted income per capita of the source country and distance are found to be statistically insignificant. Contrary to what we find, one would expect as income grows, individuals tend to have more money allocated for investment and the GCC would have benefited from these portfolio diversifications. Also, the farther away a source country is to a host country, the less integrated their markets are as transaction and transportation costs discourage trade and investment, unless the host country is a shelter for hiding capitals. Despite these unexpected results, most of the findings are well justified within the context of GCC as we have explained earlier.

The importance of factor market capitalization is well understood in that the GCC is the most attractive place for investment in the Middle-East and the greater African continent when investors factor in market returns, the relative easiness of capital investing and repatriation of earnings, and the stability of the individual currencies that reduces translation costs. Therefore, investors' decisions whether to reallocate existing assets or to acquire new assets as their wealth expands will likely consider the GCC over other nations for similar risks. It is not by pure coincidence that the financial openness variable (capital control) is statistically significant. As

\footnotetext{
${ }^{10}$ Contiguous dummy(takes 1 if the both source and host country share borders, 0 elsewhere,) and similar country dummy(takes 1 if the countries are politically and culturally similar) The details of the new instruments are also listed in Table 1.
} 
it is well understood in the literature, the lesser the barriers for capital account transactions, the greater the capital inflows. Alfaro, Kalemli-Ozcan, and Volosovych (2004) have indeed shown that emerging markets with lesser financial market restrictions often attract more capital and thereby experience higher economic growth. This is evident even amongst the GCC countries; the Sultanate of Oman has implemented stiffer capital market regulations relative to other GCC members and as a result the volume of capital inflows to Oman is the lowest.

Although capital asset pricing model (CAPM) postulates a direct relationship between risk and expected return, investors do diversify their portfolio in search for both higher returns and lower risk. In fact, Grubel (1968) finds risk minimization to be the underlying motive for investors who opt for internationally diversified portfolios. Subsequent studies by Chow and Denning (1992) and Lewis (1996 and 1999) have confirmed Grubel's finding both theoretically and empirically. Default risk, however, remains the most serious threat of all since it represents a complete loss of investment and is sometimes unforeseeable due to information asymmetry. Our measure of portfolio holdings in Table 3 contains both debt and equity, with debt representing a substantial portion of the total assets. The debt to GDP ratio is one of such leading indicators that can signal to the typical risk-averse investor the ability of a nation to repay its debt. We take this into consideration by incorporating the differential debt to GDP ratio across countries in the regression equation to determine whether the ability of the GCC to meet its financial obligations at the time of maturity in relative terms can be a magnet for capital inflows to the region. The statistical significance of the differential debt to GDP ratio at the margin (10 percent level) is indicative that investors do not seem to care much about the relative degree of solvency of the GCC with respect to other countries in the panel. Much sense can be made of this finding when one peruses Table 1 of the list of countries considered as investors to the GCC. The bulk of these countries are high income OECD and non-OECD countries. Issues concerning solvency may be limited to countries such as Guinea-Bissau, Pakistan, and the Philippines.

The second column of Table 3 presents the results for total portfolio holdings with the three new additional variables included. As can gleaned, these results represent quite an improvement over those of column 1 and at the very least suggest that omissions of cultural and institutional variables lead to mis-specification bias. All three variables introduced -institutional quality, expatriates (at the 10 percent level), and religion-are statistically significant in explaining portfolio inflows. We also find that distance becomes significant at the 10 percent level while differential debt to GDP ratio is insignificant. These results are at par with the reality of the GCC. As the quality of institution in the source country relative to the GCC members decreases, investors would be more motivated to allocate their investments to GCC countries. Indeed, the quality 
of institution is a valid proxy for measuring the relative possibility of default risk of the countries. When we consider capital mobility that arises due investment reallocation, investors do have a tendency to switch from high risk home markets to lower risk foreign markets, which is observed for GCC markets. The significance of religion also makes sense; as we have noted, there exists a GCC bias when it comes to portfolio allocation. The results therefore suggest that when both source and host country's populations are dominated by Islamic beliefs, investors do care about religion whether they are investing at home or overseas. With the millions of Muslims worldwide and the growth of Islamic financial products in the international markets, it is not surprising that portfolio allocation is likely to be biased towards Islamic products as investments to securities may be governed by strict rules since the Qu'ran forbid Muslims from earning income through interest-based activities.

Lastly, our finding that the level of expatriates is a relevant explanatory variable in explaining portfolio inflows to the GCC is justified by the intrinsic dynamic and characteristics of the GCC labor markets in that over 80 percent of the population are foreigners. As can be understood, expatriates foment stronger financial connections between source and host countries since a portion of their hard earned income has to be sent back home to maintain direct and extended families or to invest for retirements. This bond between source and host countries creates an interesting quid-pro-quo relationship. Source countries invest in the GCC partly because a large portion of their citizens reside there and as such a market segment for their products is already in place. The GCC reciprocates with investment in the source countries in search for higher profits.

The last column of Table 3 presents the results of the estimation of the total portfolio holdings of Equation 16 using the IV method. Only the variables that are significant in column 2 are incorporated in the regression equations. Since the IV estimation indicates that the import volume of host country from source country is to be considered as endogenous, we use the import variable as an instrument and rerun the model. All the variables continue to be significant but with larger coefficient estimates, confirming that cultural and institutional variables amongst others matter in explaining portfolio inflows to GCC.

For comparison purposes, we run a similar set of of panel data regressions using source and host countries from the OECD members and present the results for the determinants of foreign bond holdings in Table 4 . We observe that in columns 1 and 2 the regular explanatory variables continue to be useful in explaining the bilateral portfolio holdings, which confirm Lane and Milesi-Feretti's (2008) findings. Amongst the new variables introduced, relative institutional quality was the only variable found to be statistically significant for the OECD countries. The 
results show that the volume of expatriates does not play a significant role in explaining bilateral portfolio holdings across OECD members. This could be understood by the difference in labor dynamics between OECD countries and the GCC countries. The last column of Table 4 contains the IV estimation results. It can be observed that the results are almost similar to the OLS estimations. We also note the existence of a bond Euro bias as the coefficient estimates of EMU is statistically significant at the $1 \%$ level in all regressions, indicating that European investors exhibit a strong preference towards their own markets at the time of diversifying their portfolio.

Since a large portion of total portfolio inflows to the GCC consists of debts, we also investigate the determinants of pure bond holdings and present the results in Table 5. On average these results are similar to those reported in Table 3, with one exception: the PPP adjusted real income per capita of source country is now statistically significant using both OLS and IV methods regardless of whether the cultural and institutional variables are incorporated in the equation or not. Other notable results are that institutional quality, the volume of expatriates, and religion play a significant role in explaining portfolio inflows to GCC. We further observe that our dummy variable, GCC, is positive and significant, indicating that there is a "GCC bias" in the debt inflows as well. This is an important finding that appears to suggest that in GCC and European regions where economic integration has reached or is near its highest stagemonetary union-, investors prefer to allocate their portfolio mostly within their respective regions. Although this pattern may further enhance relationships among member countries, it carries the drawback of limiting income smoothing via portfolio diversification. In fact, this is a more serious issue for GCC countries where output diversification is quite limited. With $50 \%$ or less of their total output coming from the non-oil sector, GCC investors bear higher risks due to the impediment of further diversifying their portfolio across industries within member countries. We therefore conjecture that for the debt inflows to the host countries, GCC investors' priority is to allocate their wealth to Sharia'a-compliant debt instruments from Islamic markets. This also partly explains the GCC bias observed because investors adhere to religious norms. ${ }^{11}$ When we compare these results with Table 4 we note a similar bias, namely, a bond "Euro" bias in the regression of total debt securities. ${ }^{12}$

\footnotetext{
${ }^{11}$ Due to data restrictions, we have only Bahrain and Kuwait listed as both source and host countries. Although the other GCC member countries do possess external assets, e.g., the UAE's Abu Dhabi Investment Authority (ADIA), Qatar Investment Authority have external assets around 875 billion USD, the geographic distribution of those assets has not been published.

${ }^{12}$ The regional bias contends that investors tend to hold a large share of their assets portfolio within their geographical boundaries even when they have the opportunities to spread their investments equally in various markets. These patterns are consistently observed lately, despite the overall increase in the volume of international assets holdings that takes place due to financial market integration and economic booms that have occurred in other parts of the world. Lane and Milesi Ferretti (2005) Lane (2006) and Maela (2008) have also found portfolio Euro bias bias in their studies.
} 


\subsection{Robustness Checks}

In order to ascertain whether the determinants of portfolio inflows to GCC uncovered in Tables 3 and 5 are not sensitive to the estimation method used, we conduct a robustness check using the Tobit model. This estimation technique was chosen due the special feature of the CPIS data, which contains a large number of observations for portfolio inflows from other countries to the GCC markets that have a value of zero. This implies that a significant portion of portfolio inflows to the GCC markets from our source countries sample is negligible. Additionally, we test for the institutional quality with a different measure, the relative freedom index of source countries $(0$ is minimum: not free and 15 is maximum: perfectly free). The results are documented in Table 6 confirming the GCC bias ${ }^{13}$ the importance of institutional quality, the volume of expatriates, and religion among other variables in explaining portfolio inflows to the GCC. Therefore our findings are robust, eclectic, and insightful.

\section{Concluding Remarks}

Over the last few decades, the GCC countries have capitalized on oil revenue growth to implement macroeconomic structural reforms capable of enhancing their profile in the global market. With the changes in ownership and immigration laws, stable currencies, and the billions of dollars poured into infrastructure projects, tourism, real estate, and petrochemical, the GCC has sent a strong message to investors that economic opportunities loom in the region and by partnering with the government their investments are relatively safer for similar returns elsewhere. What we have observed thus far from reading the literature is that massive capital inflows to the GCC are due to growth in oil prices and the highly inelastic demand for oil at the world level. However, a full accounting of the underlying determinants of portfolio inflows to the GCC countries is still missing. This paper has added to the literature in producing a comprehensive analysis of the patterns of cross-border portfolio investments in the region. Building on the footprints of Obstfeld and Rogoff (2001)'s two-country model and the extension of their work by Lane and Milesi-Feretti (2008) to n-country model, we use panel data analysis along with the CPIS data of the IMF and data from other reliable sources to uncover the determinants of portfolio inflows to the GCC countries. We extend our analysis to the OECD members in search of a benchmark for comparing the results obtained for the GCC. For each measure of portfolio inflows, whether it is pure bond or total portfolio holdings (bonds and equity), we

\footnotetext{
${ }^{13}$ The GCC bias is again present, providing convincing evidence that when GCC investors make the decision to diversify their portfolio, they-at least the two members, Bahrain and Kuwait, — primarily choose other GCC countries to allocate their wealth.
} 
conduct a battery of checks using different estimation techniques (IV and Tobit) to assess the robustness of our findings.

The empirical results show that international portfolio inflows to GCC markets are primarily explained by a GCC bias similar to the European bias of Lane-Milesi and Feretti (2008)(a sizable portion of the capital inflows to the GCC countries comes from the GCC members themselves), cultural affinities and institutional quality. We also find that portfolio investments to the GCC are explained by bilateral linkages; mainly, the volume of import of host countries from the source countries, strong fiscal position of the GCC markets, world market capitalization, capital market liberalization, and income levels of the source countries. These results hold irrespective of the estimation method used to document the patterns of portfolio holdings. This paper offers a valuable insight into the modeling of cross-border portfolio inflows to the GCC region. It shows that institutional quality, the volume of expatriates living in the GCC, and religion are all relevant variables that statistically and significantly explain capital inflows to the GCC. 


\section{References}

Alfaro, L., Kalemli-Ozcan, S., \& Volosovych, V. (2005). Why doesn't capital flow from rich to poor countries? An empirical investigation. Review of Economics and Statistics 90, 347368.

ew of Economics and Statistics 90, 347-368.

Alkulaib,Y.A., Najand, M., \& Mashayekh, A. (2008). Dynamic linkages among equity markets in the Middle East and North African countries. Forthcoming in Journal of Multinational Financial Management.

Baele, L., Ferrando, A., Hördahl, P.,Krylova, E., Monnet, C., 2004. Measuring Financial Integration in the Euro area. European Central Bank, Occasional Paper No:14.

Balli, F., Louis, R.,J., \& Osman, M. (2009). International Portfolio Inflows to GCC Markets: Are There Any General Patterns? Review of Middle East Economics and Finance: Vol. 5 No. 2 Article 3.

Chow, K. V., \& Denning, K. C. (1992). The symmetry and stability of word equity markets: Getting to the issue on international portfolio diversification. Journal of Multinational Financial Management 2, 35-58.

Bley, J., \& Chen, K.H. (2006). Gulf Cooperation Council (GCC) stock markets: The dawn of a new era. Global Finance Journal 17, 75-91.

Chinn, M., \& Hiro I. (2007). A new measure of financial openness. Forthcoming Journal of Comparative Policy Analysis.

Fasano, U., \& Iqbal, Z. (2003). GCC Countries: from oil dependence to diversification, International Monetary Fund, Washington D.C.

French, K., \& Poterba, J. (1991). International diversification and international equity markets. American Economic Review 81, 222-226.

Guetat, I., \& Serranito, F. (2007). Income convergence within the MENA countries: A panel unit root approach. The Quarterly Review of Economics and Finance 46, 685-706.

Grubel, H. L. (1968). Internationally diversified Portfolios: Welfare Gains and Capital Flows. American Economic Review 58, 1299-1314.

Habib, M., and L. Zurawicki (2002) Corruption and Foreign Direct Investment. Journal of International Business Studies, 33.

Hourani, A., Khoury, P.S., Wilson, M.C. (2004) The Modern Middle East: a Reader, London, I. B. Tauris, 2004

Husted, B.,W. (1999) Wealth, Culture, and Corruption. Journal of International Business Studies 30(2), 339-359

Lane, P. (2006). Global bond portfolios and EMU. International Journal of Central Banking 2, 1-23. Also ECB Working Paper No: 553.

Lane, P., \& Milesi-Ferretti, G.M. (2005). The International Equity Holdings of Euro Area Investors. The Institute for International Integration Studies Discussion Paper Series IISDP: 104. 
Lane, P., \& Milesi-Ferretti, G.M. (2008). International investment patterns. IMF Working Paper No:134. Also Review of Economics and Statistics forthcoming.

Lagoarde-Segot,T., \& Lucey, B.M. (2007). International portfolio diversification: Is there a role for the Middle East and North Africa? Journal of Multinational Financial Management $17,401-416$.

Lewis, K. (1996). What explain the apparent lack of international consumption risk sharing? Journal of Political Economy 104, 267-297.

Lewis, K. (1999). Trying to explain home bias in equities and consumption. Journal of Economic Literature 37, 571-608.

Maela, G. (2008). EMU Effects on Stock Markets: From Home Bias to Euro Bias. International Research Journal of Finance and Economics 15, 136-158.

Mina, W. (2007). The location determinants of FDI in the GCC countries. Journal of Multinational Financial Management 17, 336-348.

Mody, A., \& Murshid, A. P. (2005). Growing up with capital flows. Journal of International Economics 65, 249-266.

Obstfeld, M., \& Rogoff K. (2001). The six major puzzles in international macroeconomics: Is there a common cause? Center for International and Development Economics Research (CIDER) Working Papers C:00-112, University of California at Berkeley.

Sadik, A.T., \& Bolbol, A.A. (2001). Capital Flows, FDI and Technology Spillovers: Evidence from Arab Countries. World Development 29, 2111-2125.

Seligson, M.A. (2007) The Impact of Corruption on Regime Legitimacy: A Comparative Study of Four Latin American Countries. Journal of Politics 64(2), 408-433.

Sørensen, B. E., Wu, Y.T., Yosha, O., \& Zhu,Y. (2007). Home bias and international risk sharing: Twin puzzles separated at birth. Journal of International Money and Finance 26, $587-613$.

Svensson, J. (2005) Eight Questions about Corruption. Journal Of Economic Perspectives, 19(3) 19-42

World Bank, (2005) Global Economic Prospects 2005: Regionalism and Development, World Bank Publication. 
Table 1: Data Description and Construction of the Variables

Variable

Foreign Portfolio Inflows

Import

Distance

Debt Market Capitalization

Equity Market Capitalization

Gross Domestic Product

CPI Index

Population

Debt Position

Capital Controls

Expatriates

Corruption and Perception Index

Common Colony

Common Language

Contiguous Dummy

Similar Country Dummy
Source and Explanations

IMF's Coordinated Portfolio Investment Survey (CPIS) for years between 2001 and 2005. In the regressions, we employ the log linearized U.S. Dollar value of the financial asset inflows to GCC markets. Survey data exists for 1997 year as well. However for 1997, the survey was not conducted extensively. Import of the GCC countries from the source countries listed below. The data source is taken from IMF's Direction of Trade Database for years 2001-2005. We employed the log linearized values of the imports.

French Research Center in International Economics (CEPII ,http://www.cepii.fr)

Domestic Debt securities and outstanding short term securities are obtained from Bank of International Settlements (BIS) Quarterly

Review. We created size of a country's total bond market capitalization as outstanding domestic market securities minus outstanding short term domestic securities plus outstanding international bonds and notes.

This data set is obtained from World Bank's World Development Indicators (WDI).

(PPP adjusted.) United Nation's National Accounts Database and authors' own calculations.

United Nation's National Accounts Database.

(In person) United Nation's National Accounts Database.

We employed the log linearized of population in person.

International Financial Statistics Database and European Commission Database.

IMF's Annual Report on Exchange Rate Arrangements and Exchange Restrictions(AREAER). We created the capital control variable using restrictions on capital account transactions. We created the capital control variable by taking the average of these binary variables for 5 year period. Details are explained in the text.

OECD's International Migration Statistics and World Bank's migration Database.

www.Tranparancy.org

CIA Factbook

CIA Factbook

French Research Center in International Economics

(CEPII ,http://www.cepii.fr)

French Research Center in International Economics

(CEPII ,http://www.cepii.fr) 
Table 2: Countries in the Data Sets

\begin{tabular}{lll} 
Source Countries & & \\
Austria & Japan & Thailand \\
Bahamas & Korea & Turkey \\
Bahrain & Kuwait & United Kingdom \\
Belgium & Macao SAR of China & \\
Bermuda & Malaysia & Host Countries \\
Canada & Malta & Bahrain \\
Cyprus & Mauritus & Kuwait \\
Denmark & Netherlands & Oman \\
Egypt & Norway & Qatar \\
France & Pakistan & Saudi Arabia \\
Germany & Philippines & United Arab Emirates \\
Guinea-Bissau & South Africa & \\
Hong Kong SAR of China & Spain & \\
Ireland & Sweden & \\
Italy & Switzerland & \\
\hline \hline
\end{tabular}

Notes: Time period is $2001-2006$ 
Table 3: The Determinants of Foreign Portfolio Holdings

\begin{tabular}{|c|c|c|c|}
\hline & Panel & Panel & IV \\
\hline IMPORT $^{h}$ & $\begin{array}{l}0.12^{* *} \\
(2.16)\end{array}$ & $\begin{array}{l}0.17^{* *} \\
(2.29)\end{array}$ & $\begin{array}{c}0.33^{* * *} \\
(3.17)\end{array}$ \\
\hline DISTANCE & $\begin{array}{l}-0.81 \\
(-1.33)\end{array}$ & $\begin{array}{l}-0.61^{* *} \\
(-1.88)\end{array}$ & \\
\hline $\mathrm{FMC}^{j}$ & $\begin{array}{c}0.22^{* * *} \\
(3.66)\end{array}$ & $\begin{array}{c}0.21^{* * *} \\
(3.48)\end{array}$ & $\begin{array}{l}0.24^{* *} \\
(2.72)\end{array}$ \\
\hline CAPITALCONTROL $^{h}$ & $\begin{array}{l}0.19^{* *} \\
(2.12)\end{array}$ & $\begin{array}{l}0.14^{* *} \\
(2.16)\end{array}$ & $\begin{array}{l}0.34^{* *} \\
(2.59)\end{array}$ \\
\hline $\mathrm{GDP}^{j}$ & $\begin{array}{c}0.18 \\
(1.42)\end{array}$ & $\begin{array}{c}0.08 \\
(0.55)\end{array}$ & $\begin{array}{l}0.29^{*} \\
(1.91)\end{array}$ \\
\hline COMMON LANGUAGE & $\begin{array}{l}1.66 \\
(0.98)\end{array}$ & $\begin{array}{l}-1.36 \\
(-0.77)\end{array}$ & \\
\hline COMMON COLONY & $\begin{array}{c}0.22 \\
(1.22)\end{array}$ & $\begin{array}{c}0.65 \\
(0.98)\end{array}$ & \\
\hline $\operatorname{DEBT}^{j-h}$ & $\begin{array}{l}0.45^{*} \\
(1.68)\end{array}$ & $\begin{array}{c}0.44 \\
(1.19)\end{array}$ & $\begin{array}{c}0.66^{* * *} \\
(3.10)\end{array}$ \\
\hline GCC & $\begin{array}{c}2.47^{* * *} \\
(7.01)\end{array}$ & $\begin{array}{c}2.49^{* * *} \\
(5.02)\end{array}$ & $\begin{array}{c}2.46^{* * *} \\
(5.67)\end{array}$ \\
\hline INSTITUTIONAL QUALITY $^{j}$ & & $\begin{array}{c}-3.60^{* *} \\
(-2.29)\end{array}$ & $\begin{array}{c}-3.18^{* * *} \\
(-2.92)\end{array}$ \\
\hline EXPATRIATES $^{j}$ & & $\begin{array}{l}1.19^{*} \\
(1.88)\end{array}$ & $\begin{array}{l}1.41^{*} \\
(1.69)\end{array}$ \\
\hline RELIGION & & $\begin{array}{c}1.58^{* * *} \\
(3.65)\end{array}$ & $\begin{array}{c}1.51^{* * *} \\
(3.54)\end{array}$ \\
\hline
\end{tabular}

Notes:Pooled panel regressions for determinants of reign Portfolio Holdings. Heteroscedasticity consistent t-statistics are given in parenthesis. Dataset is employed annual for years 2001-2006. The dependent variable is log linearized volume of source country's $(j)$ portfolio holding in the host country, $(h)$. Similarly, IMPORT ${ }^{h}$ is the log linearized import volume of host country shipped from source country. FMC $^{j}$ is defined as the source country's share of world market capitalization. DEBT ${ }^{j}$ is the debt to GDP ratio differential between source and host country. DISTANCE is the financial center distance between host and source countries in kilometers, this variable is also log linearized. GCC is a dummy variable equal to 1 if source country is a member of GCC, zero elsewhere. GDP ${ }^{j}$ is the log linearized PPP adjusted GDP per capita of source country. CAPITALCONTROL ${ }^{h}$ is the capital control adjustments of host country. Details of the variable is explained in the text. RELIGION refers a dummy variable equal to 1 when the recognized religion of the the source country is Islam, 0 elsewhere. COMMON LANGUAGE is binary variable takes one when both source and host country have same language. COMMON COLONY is a binary variable takes one when both source and host country had a colonial relationship in the past. INSTITUTIONAL QUALITY ${ }^{j}$ is an index created to measure the relative quality of the institution of source countries. EXPATRIATES ${ }^{j}$ is the level of the expatriates living in the host country, originated from the source country. ${ }^{*}, * *$, and ${ }^{* * *}$ indicate that the relevant coefficient is significant at $10 \%, 5 \%$, and $1 \%$ levels, respectively. 
Table 4: The Determinants of Foreign Bond Holdings

\begin{tabular}{|c|c|c|c|}
\hline & $\begin{array}{c}\text { Host: OECD } \\
\text { Source: OECD } \\
\text { Panel }\end{array}$ & $\begin{array}{c}\text { Host:OECD } \\
\text { Source: OECD } \\
\text { Panel }\end{array}$ & $\begin{array}{c}\text { Host:OECD } \\
\text { Source: OECD } \\
\text { IV }\end{array}$ \\
\hline $\mathrm{FMC}^{j}$ & $\begin{array}{c}0.52^{* * *} \\
(4.28)\end{array}$ & $\begin{array}{c}0.46^{* * *} \\
(4.11)\end{array}$ & $\begin{array}{c}0.49^{* * *} \\
(3.11)\end{array}$ \\
\hline $\operatorname{DEBT}^{j-h}$ & $\begin{array}{l}0.28^{* *} \\
(2.01)\end{array}$ & $\begin{array}{l}0.24^{* *} \\
(1.99)\end{array}$ & $\begin{array}{l}0.44^{* *} \\
(2.13)\end{array}$ \\
\hline EMU & $\begin{array}{c}1.82^{* * *} \\
(5.66)\end{array}$ & $\begin{array}{c}2.15^{* * *} \\
(6.32)\end{array}$ & $\begin{array}{c}2.17^{* * *} \\
(3.13)\end{array}$ \\
\hline CAPITALCONTROL $^{h}$ & $\begin{array}{c}0.25^{* * *} \\
(3.04)\end{array}$ & $\begin{array}{c}0.39^{* * *} \\
(3.12)\end{array}$ & $\begin{array}{l}0.33^{* *} \\
(3.02)\end{array}$ \\
\hline DISTANCE & $\begin{array}{c}-0.64 \\
(-0.29)\end{array}$ & $\begin{array}{c}-0.14^{*} \\
(-1.79)\end{array}$ & \\
\hline IMPORT $^{h}$ & $\begin{array}{c}0.58^{* * *} \\
(3.18)\end{array}$ & $\begin{array}{l}0.54^{* *} \\
(3.77)\end{array}$ & $\begin{array}{l}0.65^{* *} \\
(4.01)\end{array}$ \\
\hline $\mathrm{GDP}^{j}$ & $\begin{array}{l}0.25^{* *} \\
(2.12)\end{array}$ & $\begin{array}{c}0.08^{* *} \\
(2.19)\end{array}$ & $\begin{array}{l}0.08^{* *} \\
(2.25)\end{array}$ \\
\hline COMMON LANGUAGE & $\begin{array}{c}0.45 \\
(1.06)\end{array}$ & $\begin{array}{c}0.16 \\
(1.32)\end{array}$ & \\
\hline COMMON COLONY & $\begin{array}{l}0.19^{*} \\
(1.67)\end{array}$ & $\begin{array}{c}0.44 \\
(1.17)\end{array}$ & \\
\hline INSTITUTIONAL QUALITY ${ }^{j}$ & & $\begin{array}{l}-0.57^{*} \\
(-1.81)\end{array}$ & $\begin{array}{l}-0.23^{* *} \\
(-2.02)\end{array}$ \\
\hline EXPATRIATES $^{j}$ & & $\begin{array}{c}-0.18 \\
(-0.12)\end{array}$ & $\begin{array}{c}0.11 \\
(0.16)\end{array}$ \\
\hline
\end{tabular}

Panel regressions are done for country by country total portfolio holdings. Host refers to the classification of the domestic country. Source refers to the classification of the country issuing the foreign asset. For example, when we have "Host: OECD, Source: OECD" this limits the sample to country pairs in which the host country is an OECD member while the source country is taken from the sample of OECD. OECD includes Australia,Austria, Belgium, Canada, Denmark, Finland, France, Germany, Greece, Ireland, Italy, Iceland, Japan, Korea Republic, Netherlands, Norway, New Zealand, Portugal, Spain,Sweden, Switzerland, UK, and US. non-EMU: Australia, Canada, Denmark, Iceland, Japan, Korea Republic, Norway, New Zealand, Sweden, Switzerland, UK, and US.Heteroscedasticity consistent t-statistics are given in parenthesis. Dataset is employed annual for years 2001-2006. The dependent variable is log linearized volume of source country's ( $j$ ) portfolio holding in the host country, $(h)$. Similarly, IMPORT ${ }^{h}$ is the log linearized import volume of host country shipped from source country. $\mathrm{FMC}^{j}$ is defined as the source country's share of world market capitalization. DEBT ${ }^{j}$ is the debt to GDP ratio differential between source and host country. DISTANCE is the financial center distance between host and source countries in kilometers, this variable is also log linearized. $\mathrm{GDP}^{j}$ is the log linearized PPP adjusted GDP per capita of source country. CAPITALCONTROL ${ }^{h}$ is the capital control adjustments of host country. Details of the variable is explained in the text. RELIGION refers a dummy variable equal to 1 when the recognized religion of the the source country is Islam, 0 elsewhere. COMMON LANGUAGE is binary variable takes one when both source and host country have same language. COMMON COLONY is a binary variable takes one when both source and host country had a colonial relationship in the past. level of the expatriates living in the host country, originated from the source country. EMU is a dumy variable equal to 1 if host country is a member of EMU, zero elsewhere. ${ }^{*},{ }^{* *}$, and ${ }^{* * *}$ indicate that the relevant coefficient is significant at $10 \%, 5 \%$, and $1 \%$ levels, respectively. 
Table 5: The Determinants of Foreign Investment Inflows: Debt Holdings

\begin{tabular}{|c|c|c|c|}
\hline & Panel & Panel & IV \\
\hline IMPORT $^{h}$ & $\begin{array}{l}0.11^{* *} \\
(2.24)\end{array}$ & $\begin{array}{l}0.12^{* *} \\
(2.23)\end{array}$ & $\begin{array}{c}0.15^{\text {*** }} \\
(2.66)\end{array}$ \\
\hline DISTANCE & $\begin{array}{c}-0.77 \\
(-1.58)\end{array}$ & $\begin{array}{c}-0.71 \\
(-1.59)\end{array}$ & \\
\hline $\mathrm{FMC}^{j}$ & $\begin{array}{l}0.18^{* *} \\
(2.34)\end{array}$ & $\begin{array}{l}0.18^{* *} \\
(2.44)\end{array}$ & $\begin{array}{c}0.19^{* * *} \\
(2.65)\end{array}$ \\
\hline CAPITALCONTROL $^{h}$ & $\begin{array}{c}0.45^{* * *} \\
(3.19)\end{array}$ & $\begin{array}{l}0.43^{* *} \\
(3.03)\end{array}$ & $\begin{array}{l}0.50^{* *} \\
(2.55)\end{array}$ \\
\hline $\mathrm{GDP}^{j}$ & $\begin{array}{l}1.62^{* *} \\
(2.55)\end{array}$ & $\begin{array}{c}1.21^{* * *} \\
(2.84)\end{array}$ & $\begin{array}{l}1.13^{* *} \\
(2.54)\end{array}$ \\
\hline COMMON LANGUAGE & $\begin{array}{c}0.78 \\
(1.56)\end{array}$ & $\begin{array}{l}0.59^{*} \\
(1.69)\end{array}$ & \\
\hline COMMON COLONY & $\begin{array}{c}0.31 \\
(0.67)\end{array}$ & $\begin{array}{c}0.32 \\
(0.22)\end{array}$ & \\
\hline $\operatorname{DEBT}^{j-h}$ & $\begin{array}{l}0.33^{* *} \\
(2.15)\end{array}$ & $\begin{array}{l}0.36^{* *} \\
(2.71)\end{array}$ & $\begin{array}{l}0.44^{* *} \\
(3.02)\end{array}$ \\
\hline GCC & $\begin{array}{c}3.45^{* * *} \\
(6.74)\end{array}$ & $\begin{array}{c}2.44^{* * *} \\
(3.24)\end{array}$ & $\begin{array}{l}2.44^{* *} \\
(6.02)\end{array}$ \\
\hline INSTITUTIONAL QUALITY ${ }^{j}$ & & $\begin{array}{c}-2.44^{*} \\
(-1.90)\end{array}$ & $\begin{array}{l}-2.49^{*} \\
(-1.93)\end{array}$ \\
\hline EXPATRIATES $^{j}$ & & $\begin{array}{l}0.88^{* *} \\
(2.15)\end{array}$ & $\begin{array}{l}0.91^{* *} \\
(2.20)\end{array}$ \\
\hline RELIGION & & $\begin{array}{c}1.68^{* * *} \\
(3.44)\end{array}$ & $\begin{array}{c}1.76^{* * *} \\
(2.89)\end{array}$ \\
\hline
\end{tabular}

Notes:Pooled panel regressions for determinants of reign Portfolio Holdings. Heteroscedasticity consistent t-statistics are given in parenthesis. Dataset is employed annual for years 2001-2006. The dependent variable is log linearized volume of source country's $(j)$ portfolio holding in the host country, $(h)$. Similarly, IMPORT ${ }^{h}$ is the $\log$ linearized import volume of host country shipped from source country. $\mathrm{FMC}^{j}$ is defined as the source country's share of world market capitalization. DEBT ${ }^{j}$ is the debt to GDP ratio differential between source and host country. DISTANCE is the financial center distance between host and source countries in kilometers, this variable is also log linearized. GCC is a dummy variable equal to 1 if source country is a member of GCC, zero elsewhere. GDP ${ }^{j}$ is the log linearized PPP adjusted GDP per capita of source country. CAPITALCONTROL ${ }^{h}$ is the capital control adjustments of host country. Details of the variable is explained $\mathrm{n}$ the text. RELIGION refers a dummy variable equal to 1 when the recognized religion of the the source country is Islam, 0 elsewhere. COMMON LANGUAGE is binary variable takes one when both source and host country have same language. COMMON COLONY is a binary variable takes one when both source and host country had a colonial relationship in the past. INSTITUTIONAL QUALITY ${ }^{j}$ is an index created to measure the relative quality of the institution of source countries. EXPATRIATES ${ }^{j}$ is the level of the expatriates living in the host country, originated from the source country. ${ }^{*}, * *$, and ${ }^{* * *}$ indicate that the relevant coefficient is significant at $10 \%, 5 \%$, and $1 \%$ levels, respectively. 
Table 6: The Determinants of Foreign Investment Inflow: Total Portfolio Holdings Tobit Estimation

\begin{tabular}{|c|c|}
\hline & Tobit \\
\hline IMPORT $^{h}$ & $\begin{array}{l}0.18^{* *} \\
(2.88)\end{array}$ \\
\hline $\mathrm{FMC}^{j}$ & $\begin{array}{l}0.41^{* *} \\
(2.03)\end{array}$ \\
\hline DISTANCE & $\begin{array}{l}-0.18^{*} \\
(-1.77)\end{array}$ \\
\hline $\operatorname{DEBT}^{j-h}$ & $\begin{array}{c}0.31 \\
(1.61)\end{array}$ \\
\hline COMMON LANGUAGE & $\begin{array}{l}0.11^{*} \\
(1.67)\end{array}$ \\
\hline COMMON COLONY & $\begin{array}{c}0.30 \\
(1.60)\end{array}$ \\
\hline CAPITALCONTROL $^{h}$ & $\begin{array}{l}0.46^{* *} \\
(2.47)\end{array}$ \\
\hline GCC & $\begin{array}{c}2.70^{* * *} \\
(4.40)\end{array}$ \\
\hline $\operatorname{GDP}^{j}$ & $\begin{array}{l}1.87^{* *} \\
(2.23)\end{array}$ \\
\hline FREEDOM INDEX ${ }^{j}$ & $\begin{array}{c}-2.61^{* * *} \\
(-3.05)\end{array}$ \\
\hline EXPATRIATES $^{j}$ & $\begin{array}{l}1.41^{* *} \\
(2.61)\end{array}$ \\
\hline RELIGION & $\begin{array}{l}1.95^{* *} \\
(4.53)\end{array}$ \\
\hline
\end{tabular}

Estimation Method:Cencored Normal TOBIT. Sub-Samples used in the regression are explained in the text. Dataset is employed annual for years 2001-2006. The dependent variable is log linearized volume of source country's $(j)$ portfolio holding in the host country, $(h)$. Similarly, $\mathrm{IMPORT}^{h}$ is the log linearized import volume of host country shipped from source country. FMC ${ }^{j}$ is defined as the source country's share of world market capitalization. DEBT ${ }^{j}$ is the debt to GDP ratio differential between source and host country. DISTANCE is the financial center distance between host and source countries in kilometers, this variable is also log linearized. GCC is a dummy variable equal to 1 if source country is a member of GCC, zero elsewhere. GDP ${ }^{j}$ is the log linearized PPP adjusted GDP per capita of source country. CAPITALCONTROL ${ }^{h}$ is the capital control adjustments of host country. Details of the variable is explained in the text. RELIGION refers a dummy variable equal to 1 when the recognized religion of the the source country is Islam, 0 elsewhere. COMMON LANGUAGE is binary variable takes one when both source and host country have same language. COMMON COLONY is a binary variable takes one when both source and host country had a colonial relationship in the past. FREEDOM INDEX ${ }^{j}$ is an index created to measure the relative quality of the institution of source countries. EXPATRIATES ${ }^{j}$ is the level of the expatriates living in the host country, originated from the source country.*, ${ }^{* *}$, and ${ }^{* * *}$ indicate that the relevant coefficient is significant at $10 \%, 5 \%$, and $1 \%$ levels, respectively. 